\title{
Computational fluid dynamics analysis of an innovative start-up method of high temperature fuel cells using dynamic 3d model
}

\author{
Jakub Kupecki ${ }^{1, *}$, Dawid Mich², Konrad Motylinski ${ }^{3}$ \\ ${ }^{1}$ Instytut Energetyki, Zakład Procesów Cieplnych, Augustówka 36, 02-981 Warszawa \\ ${ }^{2}$ Instytut Energetyki, Zakład Procesów Cieplnych, Augustówka 36, 02-981 Warszawa \\ ${ }^{3}$ Instytut Energetyki, Zakład Procesów Cieplnych, Augustówka 36, 02-981 Warszawa \\ "Corresponding author: e-mail: jakub.kupecki@ien.com.pl
}

\begin{abstract}
The article presents a numerical analysis of an innovative method for starting systems based on high temperature fuel cells. The possibility of preheating the fuel cell stacks from the cold state to the nominal working conditions encounters several limitations related to heat transfer and stability of materials. The lack of rapid and safe startup methods limits the proliferation of MCFCs and SOFCs. For that reason, an innovative method was developed and verified using the numerical analysis presented in the paper. A dynamic 3D model was developed that enables thermo-fluidic investigations and determination of measures for shortening the preheating time of the high temperature fuel cell stacks. The model was implemented in ANSYS Fluent computational fluid dynamic (CFD) software and was used for verification of the proposed start-up method. The SOFC was chosen as a reference fuel cell technology for the study. Results obtained from the study are presented and discussed.
\end{abstract}

Keywords: CFD, dynamic modeling, start-up, SOFC.

\section{INTRODUCTION}

Stationary power systems based on high temperature fuel cells such as solid oxide fuel cells (SOFC) and molten carbonate fuel cells (MCFC) are designed to operate steadily with a limited number of transitional modes, such as power reduction from full to part-load, shutdowns and start-ups ${ }^{1-3}$. The outstanding feature of solid oxide fuel cells is their ability to operate with number of different fuels including alcohols ${ }^{4}$, hydrocarbons $s^{5}$, pure hydrogen ${ }^{5-7}$, biofuels ${ }^{8}$ and energy carriers which can be converted to hydrogen-rich gas, including ammonia ${ }^{9}$ and dimethyl ether ${ }^{10}$. Additionally, a future potential of solid oxide fuel cells can be foreseen in power-to-gas technologies. Once the cells are adapted to operate in the regenerative mode (SOEC - solid oxide electrolysis cell), the functionality of technology can be extended and new market opportunities can be seen. To make this possible the advent of stable materials for the SOEC electrodes is necessary. The attention Is also drawn to the reversible solid oxide cells ( $\mathrm{rSOC}$ ) which can smoothly switch between the SOFC and SOEC modes and backwards. Such a technology allows to complement the existing grid stabilization technologies and allow for the dynamic dispatch of intermittent energy sources.

The capability of SOFC and MCFC for dynamic operation is very limited and in most cases is insufficient for load-following power units. This is due to the long-time constant in the heating-up and cooling-down of fuel cell stacks ${ }^{11}$, performance degradation due to thermal cycling ${ }^{12}$, and high thermal capacity of the entire system. It is generally believed that such systems should therefore operate steadily and that cycling is to be avoided ${ }^{13}$. In recent years, a substantial technological process was developed and several issues related to the voltage drop due to the electrical and thermal cycling have now been resolved.

At the power output in the range of sub-kilowatts up to several kilowatts, typically $900-5.000 \mathrm{~W}$, the system can be designed in such a way that several start-ups and shutdowns can be safely completed per year. In the given power range the applied technology is mostly limited to solid oxide fuel cells, which have a strong position in low power systems. Their application in stationary power generation is typically known under micro-combined heat and power generators (micro-CHP). Systems of this sort are highly integrated units that can either operate in connection to the electrical grid or off-grid, for example in remote locations ${ }^{14}$.

Off-grid units require effective technical means to deliver the start-up procedure in a short period of time, and at minimized expense energy-wise. Moreover, highly efficient systems capable of thermal self-sufficiency during transitional modes offer several advantages over units which require grid support for electrical heaters to complete the start-up procedure.

The present study was oriented at developing an innovative method which can:

- utilize the regular fuel used in the system during steady-state operation to deliver the start-up procedure;

- assure safe conditions during transients - preventing cathode reduction and/or anode oxidation;

- shorten the start-up time.

As a result, an innovative method together with technical means was developed and is described in a patent ${ }^{15}$. It was verified at the level of a single repeatable unit (SRU) in an SOFC stack. The concept will be discussed further using solid oxide fuel cells as a reference technology.

\section{A REFERENCE SYSTEM WITH SOLID OXIDE FUEL CELLS}

Development of the new method was driven mainly by the need to overcome several limitations of stationary micro-cogenerators (micro-CHP) with solid oxide fuel cells. The first argument was the lack of cheap technical means for completion of the start-up procedure. Secondly, the limited ability to operate in off-grid locations due to the high power consumption of electric start-up heaters should be mentioned. 
A generic residential power and heat generator with solid oxide fuel cells combines the following key components:

- the fuel cell stack, typically in the range $1-3 \mathrm{~kW}^{\mathbf{1 6}}$,

- fuel processing unit, typically a steam reformer ${ }^{17}$,

- set of heat exchangers ${ }^{18}$,

- post-combustor of anodic lean fuel ${ }^{18}$,

- automation and control instrumentation and equipment ${ }^{19}$,

- hot water storage tank for low enthalpy heat utilization $^{20}$.

Additionally, the system engages elements required to guarantee a high level of thermal integration, DC/AC inverters, an air blower to supply oxidant to the cathodic compartments of the fuel cell stack, and a venting system which can be equipped with a draft fan.

Application of the proposed start-up method should correspond to the outline of the power system. Therefore, three reference units were under consideration. Examples of selected possible configurations of micro-combined heat and power (micro-CHP) generators with SOFCs are presented in Figures 1-3. Two systems are based on recirculation of the anodic gases using a high temperature blower and an ejector. The third one relies on the concept of connecting two stacks in series ${ }^{21}$.

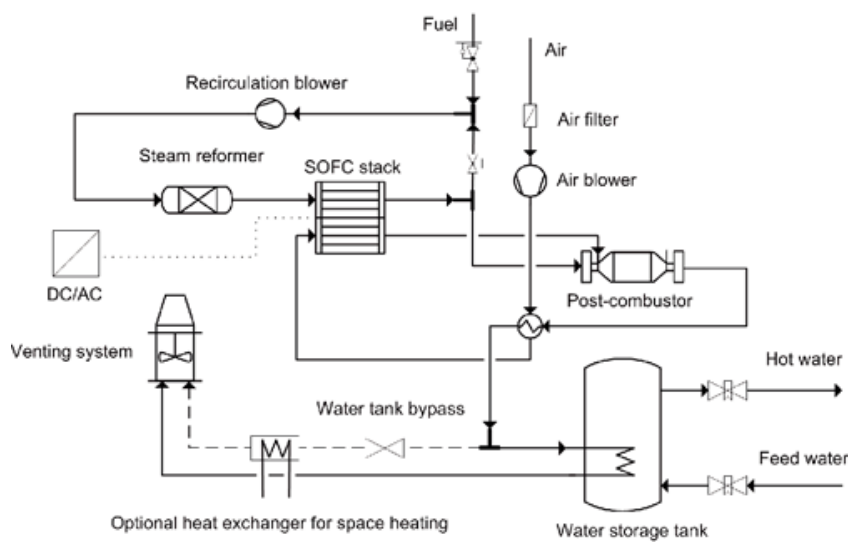

Figure 1. Micro-CHP system with recirculation of anodic stream based on a high temperature machine ${ }^{22}$

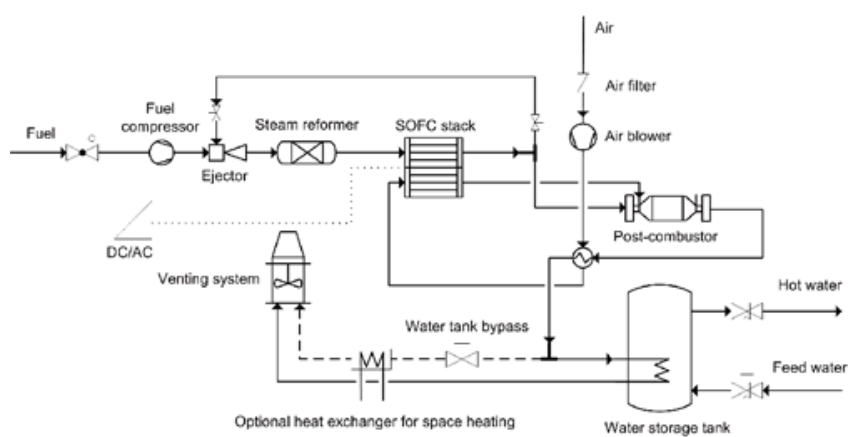

Figure 2. Micro-CHP system with recirculation of anodic stream based on an ejector ${ }^{22}$

Each of the configurations presented in Figures 1-3 requires an additional module responsible for the start-up procedure. In the case of systems 1 and 2, the presence of the recirculation loop offers additional benefits. Recirculation makes it possible to precisely control the values of parameters at the inlet to the anodic compartments of the SOFC stack.

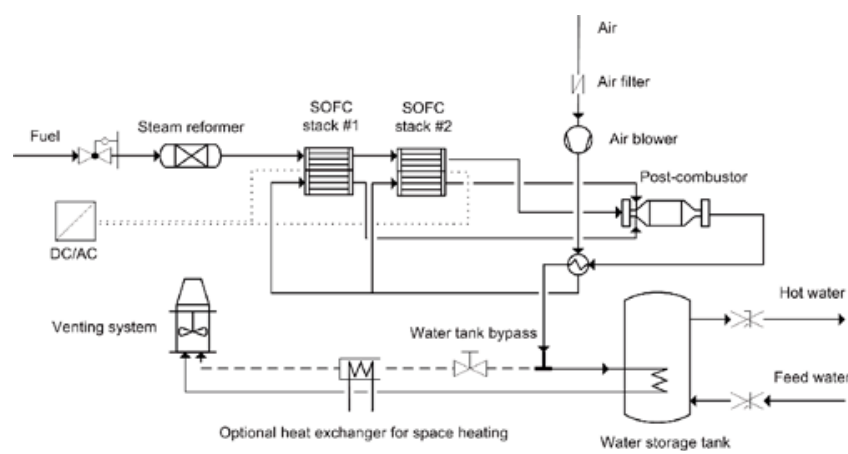

Figure 3. Micro-CHP system with two SOFC stack connected serially via the fuel line ${ }^{22}$

\section{INNOVATIVE START-UP METHOD}

The proposed method for starting up the high temperature fuel cells can be realized in two alternative ways. Both options rely on using a supplementary burner responsible for the generation of exhaust gas with the required parameters. The gas is directly supplied to the stack, eliminating therefore the presence of additional heat exchangers. The method can be applied either to the anodic or the cathodic line according to Figures 4 and 5, respectively. In the first option, the system is equipped with a start-up burner located directly in the air delivery (anodic) line, up stream of the steam reformer and the fuel cell stack. It is supplied with two streams - the fuelling gas and the start-up air. By adjusting the combustion parameters with a dedicated automation system it is possible to generate exhaust gas which is an oxygen-lean mixture directed to the anodic compartments of the SOFC stack via the steam reformer. Such composition of the gas ensures that the reductive atmosphere is maintained and that anode oxidation should not occur. Stoichiometric air-fuel ratio $\lambda$ is therefore lower than 1.0. The gradual increase in the temperature inside the start-up burner together with adjustment of the recirculated stream makes it possible to influence the rate of preheating the reformer and the stack to the nominal working temperature.

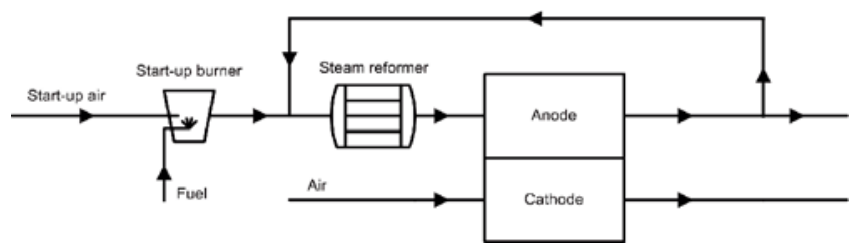

Figure 4. Start-up method using the anodic line

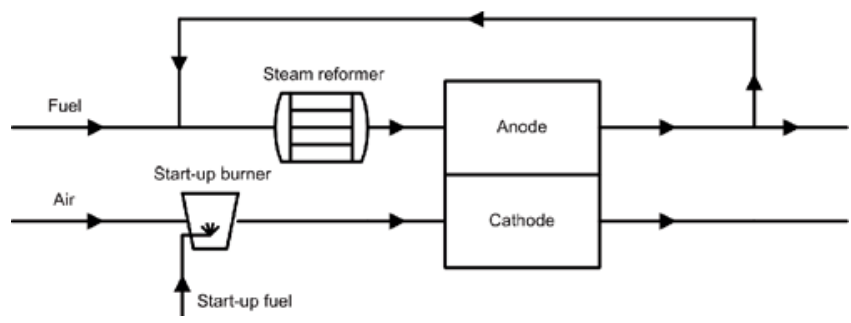

Figure 5. Start-up method using the cathodic line

Alternatively, the second option is to apply the start-up burner in the cathodic line. In this configuration control of the start-up burner is oriented at the generation of oxygen-rich exhaust gas. The value of the stoichiometric 
coefficient $\lambda$ higher than 1.0 ensures that no reduction of the cathode of the SOFC stack occurs.

Since the operation of the burner with stoichiometry corresponding to the presence of excess oxygen in the stream is easier than operating a burner with excess fuel $(\lambda<1.0)$, there is no need for recirculation of the gas from the outlet of the fuel cell stack. Additionally, since the start-up method in the second case does not directly affect the parameters in the steam reformer, the risk of a thermal shock in the catalytic bed is substantially reduced.

The proposed method relies on easy control of the temperature of the gas used for preheating the fuel cell stack. Limitations in terms of the possible temperature ramps during both starting and stopping the SOFC-based power generator were studied previously ${ }^{23}$. Additionally, the values provided by the manufacturer of a generic SOFC stack (presented in Table 1) were included as the operational constraints.

In order to verify the concept and analyze the thermal gradients, a numerical study of a single repeatable unit (SRU) of a SOFC stack was conducted.

Table 1. Allowable temperature gradients during transitional states of operation of a SOFC stack

\begin{tabular}{|l|c|c|}
\hline Parameter & Value & Comment \\
\hline $\begin{array}{l}\text { Maximum cathode inlet } \\
\text { temperature gradients, } \\
{[\mathrm{K} / \mathrm{min}]}\end{array}$ & 10 & $\begin{array}{c}\text { Heating up to the } \\
\text { operating temperature }\end{array}$ \\
\hline $\begin{array}{l}\text { Maximum cathode inlet } \\
\text { temperature gradients, } \\
{[\mathrm{K} / \mathrm{min}]}\end{array}$ & 5 & $\begin{array}{l}\text { Cooling down from the } \\
\text { operating temperature }\end{array}$ \\
\hline $\begin{array}{l}\text { Maximum temperature } \\
\text { difference anode inlet- } \\
\text { cathode inlet, }[\mathrm{K}]\end{array}$ & 50 & $\begin{array}{c}\text { Anode inlet } \\
\text { thermocouple }\end{array}$ \\
\hline
\end{tabular}

\section{COMPUTATIONAL MODEL OF A SRU}

Typically, five flow configurations of planar cells are considered: cross-flow, counter-current flow, co-current flow, serpentine-type flow, and Z-type flow. The cross-flow arrangement of the oxidant and fuel streams makes it possible to achieve relatively uniform temperature distribution at the level of a single cell and inside a fuel cell stack. For that reason, this configuration was selected for the current study. The configuration of a single repeatable

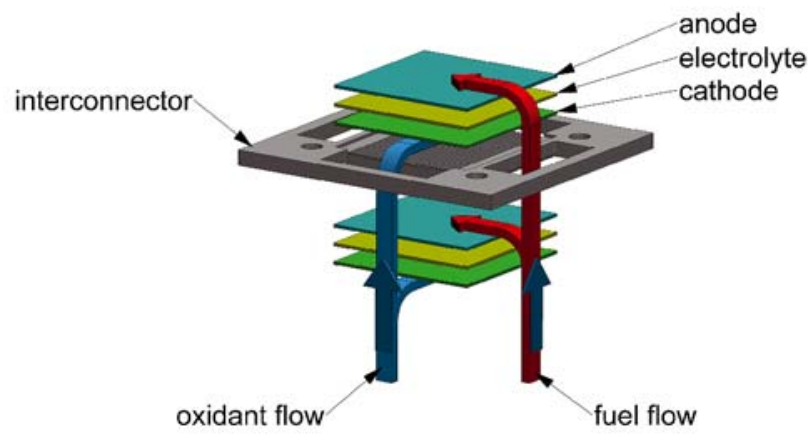

Figure 6. Schematic drawing of a single repeatable unit in a SOFC stack. Source: Fuel Cell Energy

unit of a solid oxide fuel cell with an indication of the key components is presented in Figure 6. It shows an SRU with one SOFC surrounded by two interconnects.

A short SOFC stack, developed in the Fuel Cell Department of the Institute of Power Engineering in the period 2007-2012, was used to define the key geometrical parameters of the single repeatable unit. Figure 7 shows the metallic interconnector designed for $100 \mathrm{~mm} \times 100$ $\mathrm{mm}$ solid oxide fuel cells and the nodalization of the geometry. Figure 8 shows the central part of the SRU and indicates the anodic and cathodic flow channels.

Implementation of the 3D model in ANSYS Fluent 14.0 was based on material properties of the analysed SRU. The values of materials density, specific heat capacity and thermal conductivity available in the literature were adopted and included in the simulations. The discretization of the geometry resulted in a mesh with a total of 6008636 nodes. Table 2 summarizes the key parameters used in the analysis. Table 3 provides the values of parameters defining the geometry of the SRU. The parameters of the stream supplied to the anodic compartments of SOFCs are summarized in Table 4.

While the anode is supplied with exhaust gas, the cathodic stream extracts heat from a heat exchanger, thus hot air is delivered to the inlet of the cathode. The parameters of this stream are given in Table 5.

Up to state No. 5 there was no flow of cathodic gas. Air flow was initiated when the temperature of the anodic stream exceeded $150^{\circ} \mathrm{C}$. Additional information about the model:

Table 2. The key parameters of the materials

\begin{tabular}{|l|c|c|c|}
\hline Component & Density, $\rho,\left[\mathrm{kg} / \mathrm{m}^{3}\right]$ & Specific heat, $c_{p},[\mathrm{~J} / \mathrm{kg} / \mathrm{K}]$ & $\begin{array}{c}\text { Averaged thermal conductivity, } \\
\tilde{k},[\mathrm{~W} / \mathrm{m} / \mathrm{K}]\end{array}$ \\
\hline Interconnect & 7800 & 500 & 20.00 \\
\hline Side insulation & 255 & 1000 & 24 \\
\hline SOFC & 4250 & 593 & 25 \\
\hline
\end{tabular}
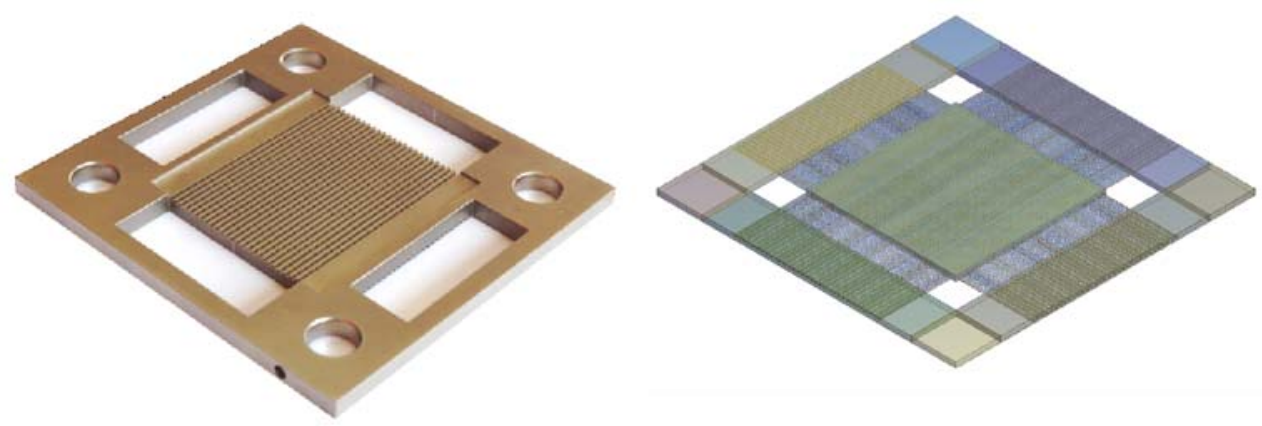

Figure 7. A single metallic interconnector (left) and the mesh generated for CFD simulations 
Table 3. Parameters defining the geometry of SRU

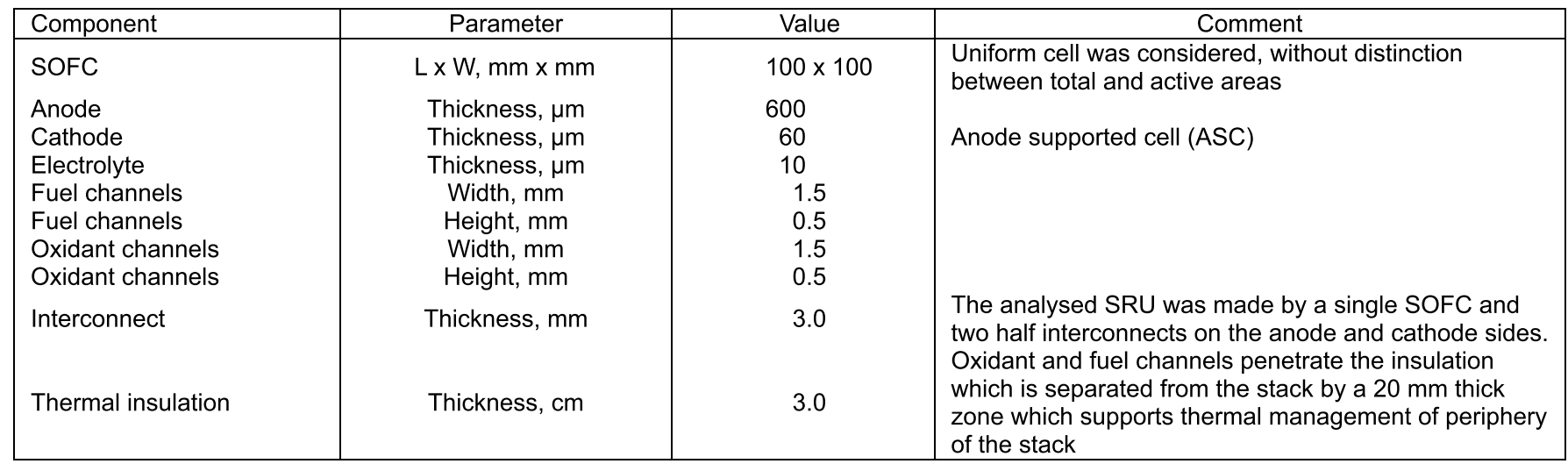

Table 4. Parameters of the gas supplied to the anodic compartments

\begin{tabular}{|c|c|c|c|c|c|}
\hline No. & $\begin{array}{c}\text { Consecutive time intervals during } \\
\text { which the parameters are constant, } \\
\text { [min] }\end{array}$ & Temperature, $\left[{ }^{\circ} \mathrm{C}\right]$ & $\begin{array}{l}\text { Mass flow, } \\
{[\mathrm{g} / \mathrm{min}]}\end{array}$ & $\begin{array}{c}\text { Specific heat } \\
\text { capacity, } \\
{[\mathrm{J} / \mathrm{kg} / \mathrm{K}]}\end{array}$ & $\begin{array}{c}\text { Thermal conductivity, } \\
{\left[10^{-2} \mathrm{~W} / \mathrm{m} / \mathrm{K}\right]}\end{array}$ \\
\hline 1 & 30 & 50 & 499.1 & 1.019 & 2.76 \\
\hline 2 & 30 & 75 & 499.5 & 1.025 & 2.93 \\
\hline 3 & 30 & 100 & 500.0 & 1.031 & 3.10 \\
\hline 4 & 30 & 125 & 500.4 & 1.037 & 3.27 \\
\hline 5 & 30 & 150 & 500.9 & 1.043 & 3.43 \\
\hline 6 & 30 & 175 & 500.9 & 1.050 & 3.59 \\
\hline 7 & 30 & 200 & 501.0 & 1.056 & 3.74 \\
\hline 8 & 30 & 225 & 501.0 & 1.063 & 3.90 \\
\hline 9 & 30 & 250 & 501.0 & 1.069 & 4.05 \\
\hline 10 & 30 & 275 & 500.9 & 1.075 & 4.20 \\
\hline 11 & 30 & 300 & 500.9 & 1.082 & 4.35 \\
\hline 12 & 30 & 325 & 500.9 & 1.088 & 4.49 \\
\hline 13 & 30 & 350 & 500.9 & 1.095 & 4.64 \\
\hline 14 & 30 & 375 & 500.9 & 1.101 & 4.79 \\
\hline 15 & 30 & 400 & 501.0 & 1.108 & 4.93 \\
\hline 16 & 30 & 425 & 501.0 & 1.114 & 5.07 \\
\hline 17 & 30 & 450 & 500.9 & 1.120 & 5.22 \\
\hline 18 & 30 & 475 & 500.9 & 1.127 & 5.36 \\
\hline 19 & 30 & 500 & 501.0 & 1.133 & 5.50 \\
\hline 20 & 30 & 525 & 500.9 & 1.140 & 5.64 \\
\hline 21 & 30 & 550 & 500.9 & 1.146 & 5.78 \\
\hline 22 & 30 & 575 & 500.8 & 1.153 & 5.92 \\
\hline 23 & 30 & 600 & 500.7 & 1.159 & 6.06 \\
\hline 24 & 30 & 625 & 500.7 & 1.165 & 6.20 \\
\hline 25 & 30 & 650 & 500.7 & 1.172 & 6.33 \\
\hline 26 & 30 & 675 & 500.7 & 1.178 & 6.47 \\
\hline 27 & 30 & 700 & 500.7 & 1.184 & 6.61 \\
\hline 28 & 30 & 725 & 500.7 & 1.190 & 6.74 \\
\hline 29 & 30 & 750 & 500.7 & 1.197 & 6.87 \\
\hline 30 & 30 & 775 & 500.7 & 1.203 & 7.00 \\
\hline 31 & 30 & 800 & 500.7 & 1.209 & 7.14 \\
\hline
\end{tabular}

- laminar flow, unsteady conditions,

- external layer of the insulation with free convection under a fixed wall temperature $\left(100^{\circ} \mathrm{C}\right)$,

- corresponding heat transfer coefficient of $5.67 \mathrm{~W} / \mathrm{m}^{2} / \mathrm{K}$,

- periodic boundary condition at the top and bottom sides of the SRU,

- pressure gradients in the fuel and oxidant channels are neglected,

- operating pressure of 1 bar.

\section{RESULTS}

Simulations were completed for several cases with 31 stages in each start-up campaign. The parameters summarized in Tables 4 and 5 were used. The key post processing objective was to investigate temperature gradients at the level of a single cell. Observation of the internal part of the $670 \mu \mathrm{m}$ thick SOFCs made it possible to identify episodes with large thermal gradients across the cell. As a result it was possible to confirm that the

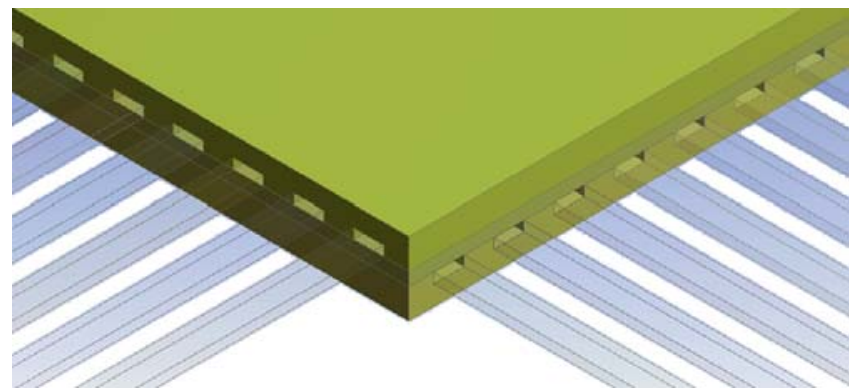

Figure 8. Geometry of a SRU with indication of the anodic and cathodic flow channels

assumed limiting value of the temperature gradient equal to $75^{\circ} \mathrm{C}$ corner-to-corner was not exceeded when the heating process was conducted according to constraints from Table 1. Figures 9a-9f present the temperature distribution in a cross-section in the central part of the solid oxide fuel cell. Thermal gradients observed dur- 
Table 5. Parameters of the stream supplied to the cathodic compartments

\begin{tabular}{|c|c|c|c|c|c|}
\hline No. & $\begin{array}{c}\text { Consecutive time intervals during } \\
\text { which the parameters are constant, } \\
\text { [min] }\end{array}$ & Temperature, $\left[{ }^{\circ} \mathrm{C}\right]$ & $\begin{array}{l}\text { Mass flow, } \\
\text { [g/min] }\end{array}$ & $\begin{array}{l}\text { Specific heat } \\
\text { capacity, } \\
{[\mathrm{J} / \mathrm{kg} / \mathrm{K}]}\end{array}$ & $\begin{array}{l}\text { Thermal conductivity, } \\
{\left[10^{-2} \mathrm{~W} / \mathrm{m} / \mathrm{K}\right]}\end{array}$ \\
\hline 5 & 30 & 50 & 249.1 & 1.150 & 3.45 \\
\hline 6 & 30 & 75 & 248.9 & 1.155 & 3.66 \\
\hline 7 & 30 & 100 & 248.8 & 1.160 & 3.87 \\
\hline 8 & 30 & 125 & 248.5 & 1.164 & 4.07 \\
\hline 9 & 30 & 150 & 248.2 & 1.169 & 4.26 \\
\hline 10 & 30 & 175 & 248.0 & 1.174 & 4.45 \\
\hline 11 & 30 & 200 & 247.7 & 1.179 & 4.64 \\
\hline 12 & 30 & 225 & 247.5 & 1.183 & 4.82 \\
\hline 13 & 30 & 250 & 247.2 & 1.188 & 5.01 \\
\hline 14 & 30 & 275 & 247.0 & 1.193 & 5.18 \\
\hline 15 & 30 & 300 & 246.8 & 1.198 & 5.36 \\
\hline 16 & 30 & 325 & 246.6 & 1.202 & 5.53 \\
\hline 17 & 30 & 350 & 246.3 & 1.207 & 5.70 \\
\hline 18 & 30 & 375 & 246.1 & 1.212 & 5.87 \\
\hline 19 & 30 & 400 & 245.8 & 1.216 & 6.03 \\
\hline 20 & 30 & 425 & 245.5 & 1.221 & 6.20 \\
\hline 21 & 30 & 450 & 245.3 & 1.225 & 6.36 \\
\hline 22 & 30 & 475 & 245.0 & 1.230 & 6.52 \\
\hline 23 & 30 & 500 & 244.7 & 1.234 & 6.68 \\
\hline 24 & 30 & 525 & 244.5 & 1.239 & 6.84 \\
\hline 25 & 30 & 550 & 244.2 & 1.243 & 7.00 \\
\hline 26 & 30 & 575 & 244.0 & 1.248 & 7.15 \\
\hline 27 & 30 & 600 & 243.7 & 1.252 & 7.31 \\
\hline 28 & 30 & 625 & 243.4 & 1.257 & 7.46 \\
\hline 29 & 30 & 650 & 243.2 & 1.261 & 7.62 \\
\hline 30 & 30 & 675 & 242.9 & 1.265 & 7.77 \\
\hline 31 & 30 & 700 & 242.6 & 1.270 & 7.93 \\
\hline
\end{tabular}
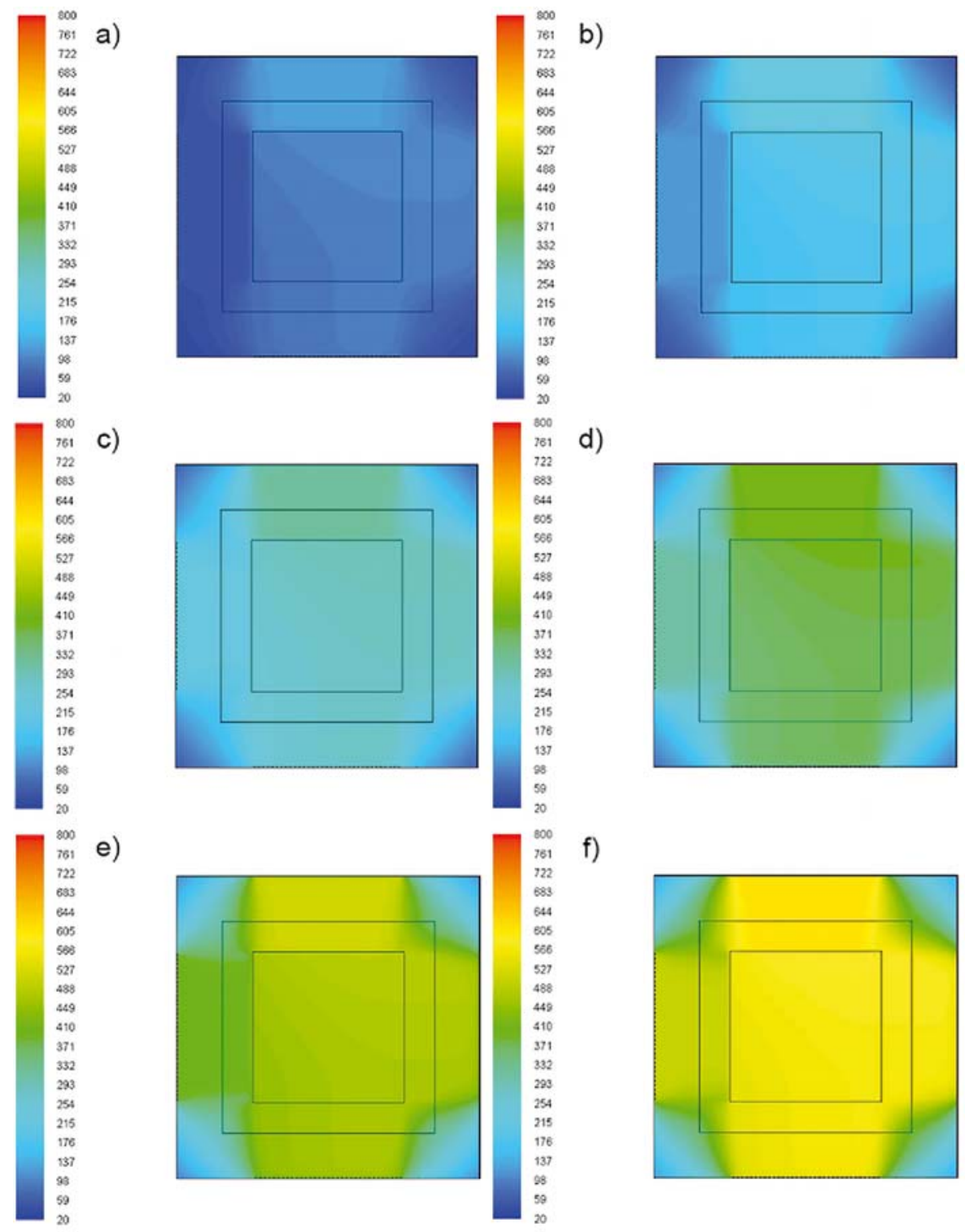

d)

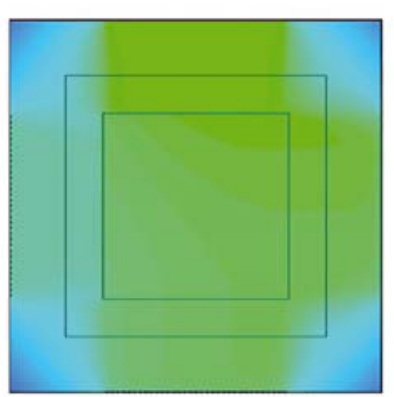

f)

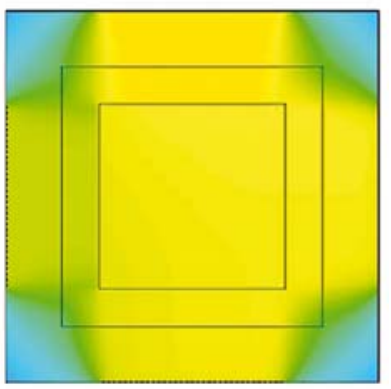

Figure 9. Temperature contours at the end of preheating stages nos. 4, 8, 12, 16, 20, 24 shown in a-f, respectively 


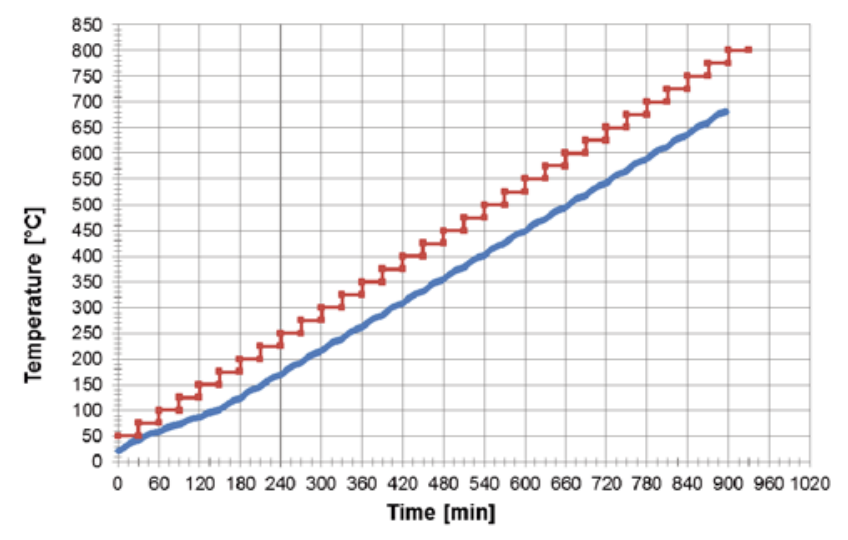

Figure 10. Internal temperature (volume averaging) of the SRU (blue) and the inlet to the anodic compartments (red squares)

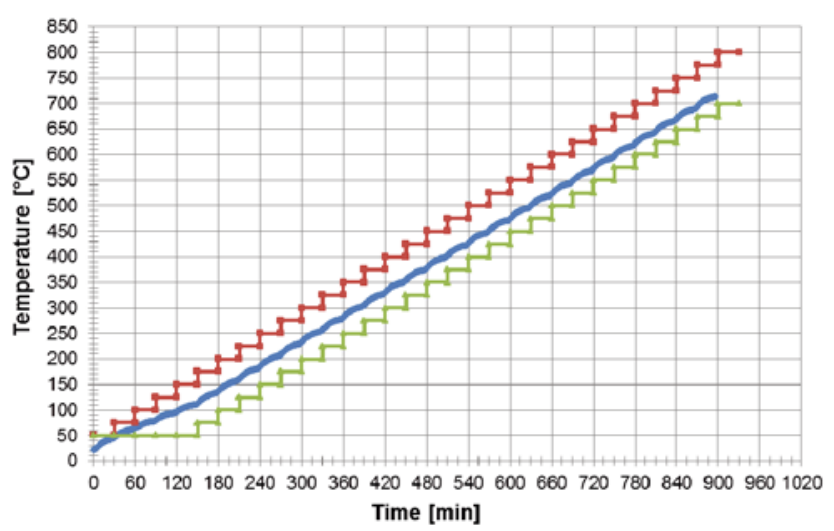

Figure 11. . Internal temperature (volume averaging) of the SRU (blue), inlet to the anodic compartments (red squares), inlet to the cathodic compartments (green triangles)

ing stages 25-31 were lower than in the early phases of preheating and therefore are not presented.

\section{CONCLUSIONS}

The results of the CFD simulations of the single repeatable unit preheated using the innovative start-up method indicated the following:

- The method finds good application in the cross-flow configuration, which is the most common design of SOFCs.

- The method allows low thermal gradients to be maintained at the level of a single cell and the SRU.

- The temperature increase in the SRU can be precisely controlled by varying the parameters at the outlet of the start-up burner, which affects the properties of the heating stream.

- Engaging both the anodic and the cathodic sides of the SOFC in a start-up makes it possible to assure a high level of temperature uniformity.

- Use of both sides of the fuel cell should therefore be considered as the optimal choice, with high application potential in the SOFC stack.

The work presented in the paper was oriented at solid oxide fuel cells only. It is however expected and confirmed by the preliminary simulations that the technique can be easily applied to molten carbonate fuel cells. The presence of carbon dioxide in the heating stream can additionally support the electrochemistry of the MCFC, since the presence of $\mathrm{CO}_{2}$ in the cathode is an absolute requirement.

\section{ACKNOWLEDGEMENTS}

The financial support from the National Center for Research and Development under the strategic project Advanced Technologies for Energy Generation, Task 4: Development of integrated technologies of fuel and energy production from biomass, agricultural wastes and other resources is gratefully acknowledged.

\section{LITERATURE CITED}

1. Singhal, S.C. \& Kendall, K. (2003). High temperature solid oxide fuel cells: fundamentals, design and applications. Elsevier.

2. Milewski, J., Swiercz, T., Badyda, K., Miller, A., Dmowski, A. \& Biczel, P. (2010). The control strategy for a molten carbonate fuel cell hybrid system. Int. J. Hydrogen Energy 35(7), 2997-3000. DOI: 10.1016/j.ijhydene.2009.06.040.

3. de Haart, L.G.J., Mougin, J., Posdziech, O., Kiviaho, J. \& Menzler, N.H. (2009). Stack degradation in dependence of operation parameters; the real-SOFC sensitivity analysis. Fuel Cells. 9, 794-804. DOI: 10.1002/fuce.200800146.

4. Jiang, Y. \& Virkar, A.V. (2001). A high performance, anode-supported solid oxide fuel cell operating on direct alcohol. J. Electrochem. Soc. 148(7), A706-A709. DOI: 10.1149/1.1375166

5. Fuel Cell Handbook 7th Edition. (2004). EG G Technical Services, Inc.

6. O'Hayre, R., Cha, S.W., Colella, W. \& Prinz, F. (2005). Fuel cell fundamentals. Wiley.

7. Yokokawa, H. (2003). Understanding materials compatibility. Ann. Rev. Mater. Rese. 33, 581-610. DOI: 10.1146/ annurev.matsci.33.022802.093856.

8. Staniforth, J. \& Ormerod, R.M. (2003). Running solid oxide fuel cells on biogas. Ionics 9(5-6), 336-341. DOI: 10.1007/ BF02376583.

9. Wojcik, A., Middleton, H., Damopoulos, I. \& Van Heerle, J. (2003). Ammonia as a fuel in solid oxide fuel cells. J. Power Sour. 118(1-2), 342-348. DOI: 10.1016/S0378-7753(03)00083-1.

10. Murray, E., Harris, S. \& Jen, H. (2002). Solid Oxide Fuel Cells Utilizing Dimethyl Ether Fuel. J. Electroch. Society, 149(9), A1127-A1131. DOI: 10.1149/1.1496484.

11. Vijay, P., Hosseini, S. \& Tade, M. (2013). A novel concept for improved thermal management of the planar SOFC. Chem. Eng. Res. Des. 91, 560-572. DOI: http://dx.doi.org/10.1016/j. cherd.2012.09.004.

12. Nakajo, A., Mueller, F., Brouwer, J., Van Herle, J. \& Favart, D. (2011). Mechanical reliability and durability of SOFC stacks. Part II: Modelling of mechanical failures during ageing and cycling. Int. J. Hydrogen Energy, 37, 9269-9286. DOI: 10.1016/j.ijhydene.2012.03.023.

13. Guan, W.B., Jin, L., Ma, X. \& Wang, W.G. (2012). Investigation of Impactors on Cell Degradation Inside Planar SOFC Stacks. Fuel Cells. 12(6), 1085-1094. DOI: 10.1002/ fuce.201200063.

14. Ferraro, M. (2015). Telecom technology. Int. Innovation. 173, 64-66.

15. Jewulski, J. \& Kupecki, J. (2015). Polish Patent PL404264-A1. Warsaw, Poland.

16. Wakui, T., Yokoyama, R. \& Shimizu, K. (2010). Suitable operational strategy for power interchange operation using multiple residential SOFC (solid oxide fuel cell) cogeneration systems. Energy 35, 740-750. DOI: 10.1016/j.energy.2009.09.029.

17. Kupecki, J., Jewulski, J. \& Badyda, K. (2011). Selection of a fuel processing method for SOFC-based micro-CHP system. Rynek Energii. 97(6), 157-162. 
18. Ang, S.M.C., Fraga, E.S., Brandon, N.P., Samsatli, N.J. \& Brett, D.J.L. (2011). Fuel cell systems optimisation e methods and strategies. Int. J. Hydrogen Energy 36, 14678-14703. DOI: 10.1016/j.ijhydene.2011.08.053.

19. Kandepu, R., Imsland, L., Foss, B.A., Stiller, C., Thorud, B. \& Bolland, O. (2007). Modeling and control of a SOFC-GTbased autonomous power system. Energy. 32, 406-417. DOI: 10.1016/j.energy.2006.07.034.

20. Ferrari, M.L. (2015). Advanced control approach for hybrid systems based on solid oxide fuel cells. App. Energy145, 364-373. DOI: 10.1016/j.apenergy.2015.02.059.

21. Wolowicz, M., Kupecki, J., Wawryniuk, K., Milewski, J. \& Motylinski, K. (2015). Analysis of nodalization effects on the prediction error of generalized finite element method used for dynamic modeling of hot water storage tank. Arch.Thermodyn. 36, 123-138. DOI: 10.1515/aoter-2015-0025.

22. Kupecki, J., Skrzypkiewicz, M., Wierzbicki, M. \& Stepien, M. (2015). Analysis of a micro-CHP unit with in-series SOFC stacks fed by biogas. Energy Procedia 75, 2021-2026. DOI: 10.1016/j.egypro.2015.07.265.

23. Kupecki, J. (2013). Analysis of micro-combined heat and power unit with solid oxide fuel cells. Doctoral dissertation, Warsaw University of Technology, OWPW, Poland.

24. Kupecki, J., Milewski, J., Szczesniak, A., Bernat, R. \& Motylinski, K. (2015). Dynamic numerical analysis of cross-, co-, and counter-current flow configurations of a $1 \mathrm{~kW}$-class solid oxide fuel cell stack. Int. J. Hydrogen Energy 40(45), 15834-15844. DOI: 10.1016/j.ijhydene.2015.07.008.

25. Kupecki, J., Jewulski, J. \& Milewski, J. (2012). Multi-Level Mathematical Modeling of Solid Oxide Fuel Cells. In Clean Energy for Better Environment. Intech, Croatia.

26. Retrieved July 21, 2014, from www.silca-online.de

27. Ki, J. \& Kim, D. (2010). Computational model to predict thermal dynamics of planar solid oxide fuel cell stack during start-up process. J. Power Sour. 195, 3186-3200. DOI: 10.1016/j. jpowsour.2009.11.129. 